\title{
Contents, Vol. 9, 1983
}

\section{International Journal of Experimental and Clinical Research in}

Advisory Board

Main Editor

. de Ajuriaguerra, Paris

P. Mandel, Strasbourg
J. Mendlewicz, Brussels

M. Matejcek, Basel

O.H. Arnold, Vienn

M. Matousek, Göteborg

Pharmacopsychiatry

C. Astrup, Tromsø

N. Matussek, Munich

Main Editors

M. Barthels, Tubingen

T. Nagatsu, Yokohama
J. Fleischhauer, St. Urban/Luzern

P. Berner, Vienna

CM. Pare, London
Th.A. Ban, Nashville, Tenn.

J.R. Boilssier, Paris

E.S. Paykel, Londo

P. Pichot, Paris

W. Boucsein, Wuppertal

J.M. Perel, Pittsburgh, Pa

W. Pöldinger, Wil/St. Gallen

M.S. Buchsbaum, Irvine, Calif.

C. Perris, Umeå

A. Coppen, Carshalton, Surrey

H. Petsche, Vienna

J.R. Davis, Chicago, 111.

A.J. Prange, Chapel Hill, N.C.

Main Editor

G Debus, Aachen

M. Pritzel, Fribourg

W. Janke, Würzburg

P. Deniker, Paris

O.J. Rafaelsen, Copenhagen

Associate Editors

J.E. Desmedt, Brussels

J.D. Rainner, New York, N.Y

P. Netter, Giessen

W.G. Dewhurst, Edmonton, Alita.

K. Rịckels, Philadelphia, $\mathrm{Pa}$.

D.M. Warburton, Early Gate, Reading

A.E. Dresse, Liège
E. Ringel, Vienna

.R. Wittenborn, New Brunswick, NJ

G Dumermuth, Zurich

T. Robbins, Cambridge 
J. Durrell, Washington, D.C

E.J. Sachar, Bronx, N.Y.

Pharmacoelectroencephalography

R.C, Elston, Chapel Hill, N.C

B. Saletu, Vienna

Main Editor

H. Künkel, Hannover

M. Sandier, Londo

H.J. Eysenck, London

N. Sartorius, Geneva

Associate Editors D. Bente Berlin

J. Fleiss, New York, N.Y.

M. Schou, Risskov

H.L. Freeman, Salford

F. Schulsinger, Copenhagen

M. Fink, St. James, N.Y.

Ch. Shagass, Philadelphia, Pa.

H. Giedke, Tubingen

J. Smythies, Birmingham, Ala.

L.R. Gjessing, Oslo

E. Strō̄mgren, Risskov

J. Glowinski, Paris

R. Takahashi, Nagasak

F.K. Goodwin, Bethesda, Md.

R. Tịssot, Geneva

J.A. Gray, Oxford

P. Grof, Hamilton, Ont

E. Usdin, Irvine, Calif.

0. Hagnell, Lund

L. Valzelli, Mila

H. Heimann, Tubingen

H. Van Prage Bronx, N.Y.

T. Helgason, Reykjavik

M. Vartanian, Moscow

W.M. Herrmann, Berlin

A. Villeneuve, Beauport, Que.

I. Hindmarch, Leeds

O. Vinar, Prague

F. Hoffmeister, Wuppertal-Elberfeld

M. Vojtëchovsky, Prague

J.G Howells, Ipswich

G. Winokur, Iowa City, Iowa

J.P. Huston, Düsseldorf

B. Woggon, Zurich

T.M. Ml, New York, N.Y

M.B.H. Youdim, Haifa

H. İtoh, Tokyo

E. Zerbin-Rüddin, Munich

P. Janssen, Beerse 
M. Jouvet, Lyon

W.P. Koella, Oberwil/Basel

H.-P. Krüger, Würzburg

St. Kubịcki, Berlin

J. Kugler, Munich

D. Kupfer, Pittsburgh, Pa

A.A. Kurland, Baltimore, Md.

M. Levitt, New York, N.Y.

G.A. Lienert, Nuremberg

M. Lipton, Chapel Hill, N.C

JJ. Lopez İbor, Madrid

S. Karger $\cdot$ Medical and Scientific Publishers $\cdot$ Basel $\cdot$ München $\cdot$ Paris $\cdot$ London $\cdot$ New York $\cdot$ Tokyo $\cdot$ Sydney

Drug Dosage
The authors and the publisher have exerted every effort to ensure that drug selection and dosage set forth in this text are in accord with current recommendations and practice at the time of publication. However, in view of ongoing research, changes in government regulations, and the constant flow of information relating to drug therapy and drug reactions, the reader is urged to check the package insert for each drug for any change in indications and dosage and for added warnings and precautions. This is particularly important when the recommended agent is a new and/or infrequently employed drug. 
rights reserved.

No part of this publication may be translated into other languages, reproduced or utilized in any form or by any means, electronic or mechanical, including photocopying, recording, microcopying, or by any information storage and retrieval system, without permission in writing from the publisher or, in the case of photocopying, direct payment of a specified fee to the Copyright Clearance Center (see 'Information for Readers and Subscribers'). c Copyright 1983 by S. Karger AG,

Printed in Switzerland by Thür AG Offsetdruck, Pratteln

No.1 
No. 2-3

Biological Psychiatry

Editorial

Mendlewicz, J

Mortality and Psychiatric Specialist Care in the Lundby Study.

Age-Standardized Death Rates in Different Forms of Psy

chiatric Services in a Total Population Investigated during a

25-Year Period

Rorsman, B.; Hagnell, O.; Lanke, J ....................................... 2

Platelet Monoamine Oxidase and Plasma Amine Oxidase: Ef

fect of Anticoagulant and Centrifugation Technique on

Platelet Yield and Enzyme Activity

Baron, M.; Levitt, M.; Gruen, R .......................................... 9

Sex Differences and Eye Movements

Bonis, M. de; Freixa i Baqué, E ............................................ 13

Neuroses and ABO Blood Types

Rinieris, P.; Rabavilas, A.; Lykouras, E.; Stefanis, C ............. 16

Pharmacopsychiatry

Editorial

Fleischhauer, J ............................................................. 19

Placebo Use in Clinical Trials on Psychotropic Drugs in France

Guelfi, J.D.; Boyer, P.; Dreyfus, J.-F .................................... 20

Intravenous Administration of Sulpiride and Heat Sensation

on the Body Surface

Kaneko, Y.; Yamamoto, Y.; Hosaka, H

Biological Psychology/Pharmacopsychology

Editorial

Janke, W

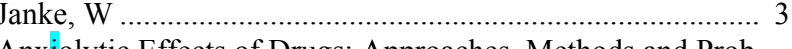

Anxiolytic Effects of Drugs: Approaches, Methods and Prob

lems

Janke, W.; Netter, P

33

Effects of Nicotine on Stimulus Sensitivity and Response Bias

in a Visual Vigilance Task

Wesnes, K.; Warburton, D.M.; Matz, B

Pharmacoelectroencephalography

Editorial

Fink, M.; Bente, D.; Künkel, H......................... 45

Significance Testing of Many Variables. Problems and Solutions

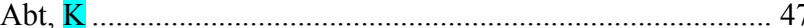

Pharmaco-EEG and Psychometric Study of the Effect of Single

Doses of Temazepam and Nitrazepam

Matejcek, M.; Neff, G.; Abt, K.; Wehrli, W ...

Topographic Approaches in Human Quantitative Pharmaco-

Electroencephalography

Sannita, W.G.; Ottonello, D.; Perria, B.; Rosadini, G.;

Timitilli, C 
Biological Psychiatry

Contingent Negative Variation and Phobic Disorders

Rizzo, P.A.; Spadaro, M.; Albani, G.; Morocutti, C

Subjective Posttraumatic Syndrome. A Comparison of Visual

and Brain Stem Auditory Evoked Responses

Rizzo, P.A.; Pierelli, F.; Pozzessere, G.; Floris, R.; Moro

cutti, $\mathrm{C}$

Evidence for the Involvement of Central Dopaminergic Recep

tors in the Acute and Chronic Effects Induced by Barbitu

rates

Feigenbaum, J.J.; Yanai, J..

83

Benzodiazepine Effect on Information Processing in General

ized Anxiety Disorder

Lapierre, Y.D.; Butter, H.J.; Oyewumi, L.K

Erythrocyte Lithium Transport Variables as a Marker fo

Manic-Depressive Disorder

Waters, B.; Thakar, J.; Lapierre, Y.D ....

Passified according to Family History

Perris, C; Eisemann, M. Ericsson, U.; Knorring, L. von;

Perris, $\mathrm{H}$

Attempts to Validin... Clasifica......................................

Based on Family Data. Symptomatological Aspects

Perris, H.; Eisemann, M.; Ericsson, U.; Knorring, L. von;

Perris, C

Prolactin and Growth Hormone Response to Levodopa in

Affective Illness

Linkowski, P ; Brauman, H; Mendlewicz, J.....

\section{Pharmacopsychiatry}

Cardiac Effects of Clomipramine Treatment. ECG and Left

Ventricular Systolic Time Intervals

Faravelli, C; Brat, A.; Marchetti, G.; Franchi, F.; Padeletti,

L.; Michelucci, A.; Pastorino, A ................................................11

Clinical Symptomatology and Computer Analyzed EEG before,

during and after Anxiolytic Therapy of Alcohol Withdrawal

Patients

Saletu, M.; Saletu, B.; Grünberger, J.; Mader, R.; Karobath,

M.........................................................................

A Dou, M., Fichte, K....................135

Intramuscular Lorazepam. A Double-Blind Comparison with

Diazepam and Placebo

Ananth, J.; Van den Steen, N...

Double-Blind Controlled Multicenter Trial Comparing Bu-

triptyline with Amitriptyline

Guelfi, J.D.; Dreyfus, J.-F.; Delcros, M.; Pichot, P.;

GEPECEP 
Biological Psychology/Pharmacopsychology

Methods and Problems of Prediction

Krauth, J

Effects of Scopolamine on Stimulus Sensitivity and Response

Bias in a Visual Vigilance Task

Wesnes, K.; Warburton, D.M

Congress Report: 12th 'German Conference on Methods in

Psychophysiology

158

Pharmacoelectroencephalography

A Computerised EEG-Analyzing System for Small Laboratory

Animals

Kropveld, D.; Chamuleau, R.A.F.M.; Popken, R.J.; Smith, J. 159 EEG Evaluation of Drug Effects in the Rat

Glatt, A.; Duerst, T.; Mueller, B.; Demieville, H 163

Effects of Antidepressants on the EEG of the Rat

Krijzer, F.; Molen, R. van der; Oorschot, R. van; Vollmer, F. 167 Sleep in Various Species of Laboratory Animals

Kleinlogel, $\mathrm{H}$. 174

Diurnal Periodicity of Lateral Asymmetries of the Visual

Evoked Potential in Healthy Volunteers

Zimmermann, P.; Görtelmeyer, R.; Wiemann, H.

Confirmatory and Exploratory Analysis Applied to Pharmaco-

EEG and Related Study Data: Contradiction or Useful

Enrichment?

Ferner, U.; Matejcek, M.; Neff, G

\section{No. 4}

Biological Psychiatry

Serum Dopamine-Beta-Hydroxylase in Diagnostic Subgroups of Depressed Patients and in Relation to Their Personality Characteristics Eisemann, M.; Ericsson, U.; Von Knorring, L.; Perris, C;

Perris, H.; Ross, $\mathrm{S}$ 
Effects of DSIIP in Man. Multifunctional Psychophysiological

Properties besides Induction of Natural Sleep

Schneider-Helmert, D.; Schoenenberger, G.A ......................... 197

Adrenal Glucocorticoids as a Required Factor in the Develop

ment of Ethanol Tolerance in Mice

Sze, P.Y.; Feigenbaum, J.J.; Yanai, J.

207

Pharmacopsychiatry

SL76002 - Effect on Gamma-Aminobutyric Acid and Dopa-mine in Animals Treated Chronically with Haloperidol Rastogi, S.K.; Rastogi, R.B.; Singhal, R.L.; Lapierre,|Y.D. . 211 Glycine: a Possible Role in Lithium's Action and Affective Illness Deutsch, S.I.;Stanley, M.;Peselow, E.D.;Banay-Schwartz, M. 215

Phenylethylamine-Like Properties of Baclofen

Wolf, M.E.; Keener, S.; Mathis, P.; Mosnaim, A.D....

219

Biological Psychology/Pharmacopsychology

Effects of Smoking on Rapid Information Processing Perfor

mance

Wesnes, K; Warburton, D.M

223

The Effects of Midazolam in Conjunction with Alcohol on

Iconic Memory and Free-Recall

Subhan, Z.; Hindmarch, 1

Pharmacoelectroencephalography

Quantitative Analysis of EEG Power Spectra in Experimental

Hepatic Encephalopathy

Popken, R.J.; Kropveld, D.; Oosting, J.; Chamuleau,

R.A.F.M...

Drug Effects on the EEG of Various Species of Laboratory

Animals

Depoortere, H.; Decobert, M.; Honoré, L

EEG Vigilance Profile as a Supplement of Psychiatric Data

Matousek, M

Author Index 